\title{
USULAN PERANCANGAN MATERIAL HANDLING YANG ERGONOMIS BAGI OPERATOR LOADING SAYURAN BUNCIS DENGAN MENGGUNAKAN METODE RASIONAL (STUDI KASUS DI PT. ABO FARM CIWIDEY)
}

\author{
${ }^{1}$ Mohammad Fadli Setiawan; ${ }^{2}$ Rino Andias Anugraha; ${ }^{3}$ Yusuf Nugroho Doyoyekti; ${ }^{4}$ Ni Made Yunita Sari Dewi \\ ${ }^{1,2,3,4}$ Program Studi Teknik Industri, Fakultas Rekayasa Industri, Telkom University \\ 1'fadlimohammad05@gmail.com, ${ }^{2}$ pak.rino@gmail.com, ${ }^{3}$ doyoyekti2010@gmail.com,.4dyunita@gmail.com
}

\begin{abstract}
Abstrak-Musculoskeletal disorders (MSDs) atau gangguan otot rangka merupakan kerusakan pada otot, saraf, tendon, ligamen, persendian, kartilago, dan discus invertebralis. Penyebab utama terjadinya MSDs adalah postur tubuh yang salah. Postur tubuh adalah posisi bagian dari tubuh yang berhubungan dengan bagian tubuh lain yang dihubungkan oleh sudut sambungan. PT ABO FARM merupakan sebuah perusahaan yang bergerak dibidang pertanian dimana memfokuskan bisnisnya pada ekspor sayuran khususnya sayuran buncis yang berada pada kawasan desa Nengkelan, kecamatan Ciwidey, kabupaten Bandung. Salah satu kegiatan pada PT ABO FARM yaitu kegiatan loading sayuran buncis dipengumpul dengan menggunakan karung. Karung yang diangkat memiliki dimensi 96 × 43 × $36 \mathrm{~cm}$ dengan kapasistas sebesar $55 \mathrm{~kg}$, padahal batas kapasitas yang direkomendasikan oleh NIOSH adalah sebesar $23 \mathrm{~kg}$. Berdasarkan hasil penelitian postur kerja operator yang sedang melakukan handling material dengan menggunakan REBA (Rapid Entire Body Assessment) diperoleh skor assessment sebesar 12. Nilai ini mengindikasikan bahwa postur kerja berada dalam posisi yang berbahaya sehingga diperlukan perbaikan saat ini juga. Maka dari itu, untuk melakukan perbaikan postur kerja maka pertama kali perlu dilakukan perbaikan pada material handling eksisting. Metode rasional merupakan suatu metode pendekatan yang sistematis. Metode ini banyak digunakan pada tahapan perancangan sebab memiliki tahapan yang jelas, sehingga dapat memberikan hasil rancangan dan produk akhir yang berkualitas. Setelah dilakukan design perancangan material handling, maka diperoleh skor pengangkatan sayuran buncis sebesar 2 , sehingga diperoleh kesimpulan bahwa produktivitas penggunaan material handling usulan meningkat sebesar 83 persen.
\end{abstract}

Kata Kunci-MSDs, PT ABO FARM, Material Handling, Buncis, REBA, Metode Rasional

\section{Pendahuluan}

Musculoskeletal disorders (MSDs) atau gangguan otot rangka merupakan kerusakan pada otot, saraf, tendon, ligamen, persendian, kartilago, dan discus invertebralis. Pada dasarnya MSDs dapat terjadi dengan dua cara :
- Kelelahan dan keletihan terus-menerus yang disebabkan oleh periode waktu yang lama, yang dihubungkan dengan aktivitas yang terus-menerus.

- Kerusakan tiba-tiba yang disebabkan oleh aktivitas yang sangat kuat/berat.

Berdasarkan sumber penelitian (Arief, 2009), MSDs disebabkan oleh beberapa faktor, diantaranya:

1. Pengulangan gerakan yang terus-menerus

2. Kekuatan (force)

3. Mechanical stress

4. Postur tubuh

5. Getaran

6. Temperatur

7. Tekanan yang disebabkan oleh keadaan luar

Postur tubuh adalah posisi bagian dari tubuh yang berhubungan dengan bagian tubuh lain yang dihubungkan oleh sudut sambungan. Postur tubuh merupakan salah satu faktor yang paling sering dihubungkan dengan faktor risiko MSDs (Arief, 2009). Dalam standardisasinya (Arief, 2009), postur tubuh manusia harus berada dalam keadaan netral. Untuk lengan atas dan bahu zona netralnya adalah santai dengan bahu sejajar dengan lantai dan pada bidang yang sama lengan berada disampingnya. Bekerja dengan posisi lengan yang jauh dari tubuh, overextended dapat meningkatkan risiko untuk terjadinya cedera. Postur tubuh dan faktor-faktor memposisikan tubuh seperti memutar batang tubuh, menaikkan posisi bahu, memutar/menengokkan kepala, mengangkat siku lengan sering dihubungkan dengan peningkatan risiko gejala MSDs.

PT. ABO FARM merupakan sebuah perusahaan yang bergerak dibidang pertanian dimana memfokuskan bisnisnya pada ekspor sayuran khususnya sayuran buncis yang berada pada kawasan desa Nengkelan, kecamatan Ciwidey, kabupaten Bandung. Salah satu proses yang terjadi pada PT. ABO FARM yaitu proses loading dimana proses ini terjadi di entitas 
pengumpul. Secara garis besar, proses loading meliputi aktivitas sebagai berikut:

\begin{tabular}{|l|l|l|}
\hline $\begin{array}{l}\text { Mengambil } \\
\text { - Mengambil } \\
\text { buncis yang } \\
\text { sudah } \\
\text { dikumpul } \\
\text { sebelumnya }\end{array}$ & $\begin{array}{l}\text { Membawa } \\
\text { buncis }\end{array}$ & $\begin{array}{l}\text { Menaikkan } \\
\text { menuju ke } \\
\text { buncis ke } \\
\text { atas truck } \\
\text { yang telah } \\
\text { tempat } \\
\text { tujuan }\end{array}$ \\
\hline
\end{tabular}
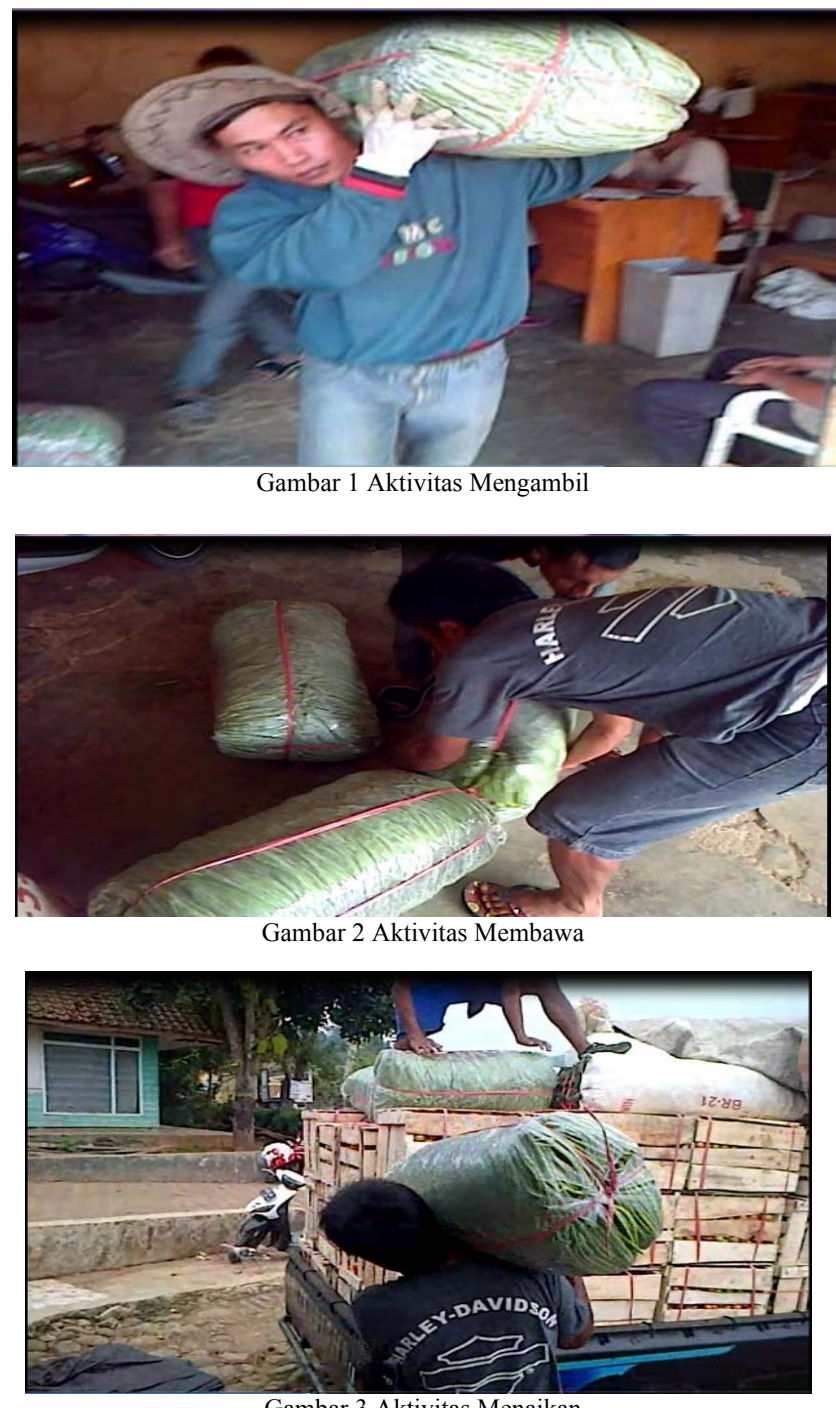

Berdasarkan hasil observasi di lapangan, material handling yang digunakan operator saat ini yaitu berupa karung plastik yang memiliki dimensi $96 \times 43 \times 36 \mathrm{~cm}$ dan kapasitas berat yaitu $55 \mathrm{~kg}$ sedangkan menurut NIOSH batas maksimal beban yang dianjurkan untuk diangkat yaitu sebesar $23 \mathrm{~kg}$. Buruknya material handling eksisting yang diperparah dengan belum adanya alat bantu bagi operator sehingga menyebabkan postur kerja operator ketika melakukan loading berada dalam posisi tidak ergonomi seperti ketika mengambil buncis tulang belakang tidak berada dalam posisi netral, kemudian ketika membawa dan menaikkan, karung buncis diletakan diatas pundak sehingga menyebabkan leher berada dalam posisi miring.

Rapid Entire Body Assesment atau biasa yang disebut dengan REBA yaitu salah satu metode yang digunakan untuk menganalisis postur tubuh manusia. Metode ini dirancang untuk mengevaluasi pekerja atau aktivitas, dimana pekerjaan tersebut memiliki kecenderungan untuk menimbulkan ketidaknyamanan seperti kelelahan pada leher, tulung punggung, leher, lengan dan sebagainya.

REBA telah mengklasifikasikan postur kerja berdasarkan nilai-nilai yang telah ditentukan, adapun nilainya sebagai berikut

TABEL 1

KLASIFIKASI NILAI REBA

\begin{tabular}{|c|l|l|l|}
\hline Skor REBA & Level Risiko & $\begin{array}{l}\text { Level } \\
\text { Tindakan }\end{array}$ & Tindakan \\
\hline 1 & $\begin{array}{l}\text { Dapat } \\
\text { diabaikan }\end{array}$ & 0 & Tidak perlu \\
\hline $2-3$ & Kecil & 1 & $\begin{array}{l}\text { Mungkin } \\
\text { diperlukan }\end{array}$ \\
\hline $4-7$ & Sedang & 2 & Perlu \\
\hline $8-10$ & Tinggi & 3 & Segera \\
\hline $11-15$ & Sangat Tinggi & 4 & Sekarang juga \\
\hline
\end{tabular}

Berdasarkan hasil evaluasi postur kerja operator dengan menggunakan REBA, peneliti mengamati bahwa postur kerja operator saat ini sangat dapat menimbulkan ketidaknyamanan bagi operator. Hal ini dapat terlihat dari hasil score level perhitungan REBA untuk ketiga postur kerja operator selama melakukan pengangkatan.

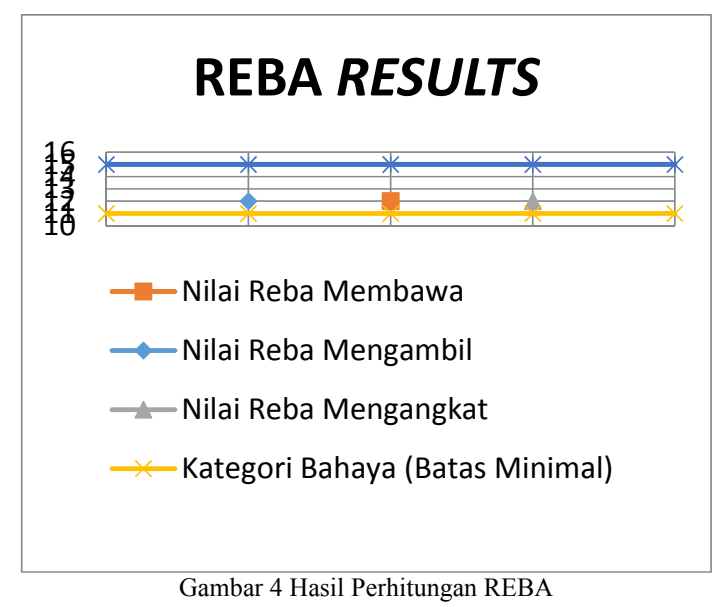

Pada grafik diatas, dapat diamati bahwa nilai REBA untuk masing-masing postur kerja berada pada interval sangat tinggi yaitu pada kategori berbahaya. Nilai REBA yang sangat tinggi mengindikasikan bahwa diperlukannya perbaikan saat ini juga. Selain menggunakan REBA, peneliti menggunakan kuesioner Standard Nordic Questionnaire (SNQ). Kuesioner SNQ digunakan untuk mengidentifikasi keluhan yang dialami 
operator dalam melakukan pekerjaannya. Kuesioner diberikan dan diisi oleh pekerja setelah melakukan pekerjaan. Data tersebut direkapitulasi dengan melakukan pembobotan untuk mengetahui tingkat keluhan muskuloskeletal pada tiap bagian tubuh dengan masing-masing kategori rasa sakit, sehingga dapat diketahui bagian tubuh mana yang paling merasakan sakit untuk dilakukan perbaikan rancangan fasilitas kerja yang dapat meminimalkan rasa sakit tersebut. Dibawah ini merupakan hasil pengolahan kuesioner SNQ masing-masing operator yang telah dilakukan.

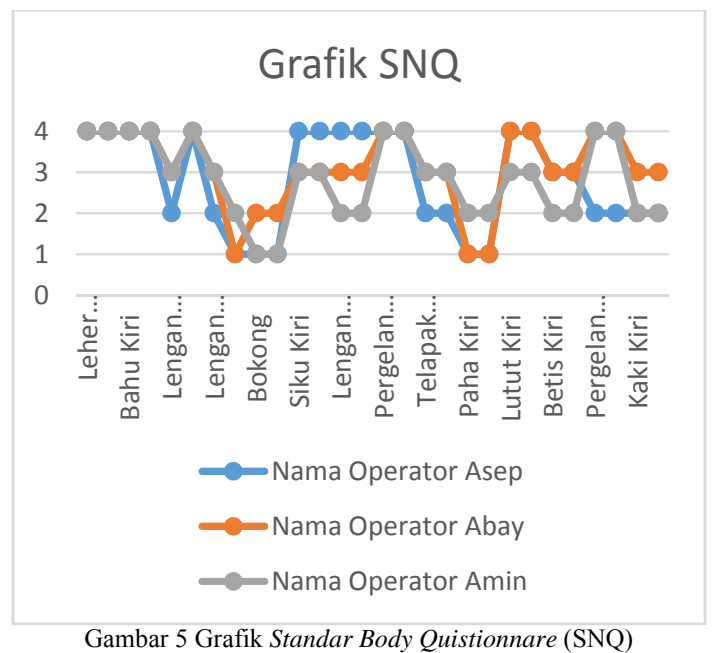

Dari grafik diatas, peneliti dapat mengamati bahwa bagianbagian tubuh seperti leher bagian atas, leher bagian bawah, bahu kiri, bahu kanan, pinggang, siku kiri, siku kanan, lengan bawah kiri, pergelangan tangan kiri, pergelangan tangan kanan, lutut kiri, lutut kanan, pergelangan kaki kiri, pergelangan kaki kanan merupakan bagian-bagian tubuh yang mengalami rasa nyeri yang sangat luar biasa disertai dengan ketegangan (kontraksi otot yang sangat hebat) sehingga operator merasakan jenuh dan kelelahan yang cukup besar.

Dengan membandingkan hasil pada nilai skor pada REBA dan hasil SNQ, peneliti dapat menarik kesimpulan bahwa postur kerja eksisting sedang mengalami masalah. Maka dari itu, untuk mengatasi masalah postur kerja yang tidak sesuai, maka diperlukan perancangan material handling yang tepat bagi operator loading sehingga dapat mengurangi level risiko MSDs.

\section{METODOLOGI PENELITIAN}

Model konseptual ini terdiri dari 3 bagian yaitu yang pertama bagian input. Bagian ini menggambarkan data-data yang akan dikumpulkan untuk menyelesaikan penelitian ini. Adapun data-data yang dikumpulkan meliputi, data keluhan operator, data antropometri, dan data penilaian eksisting postur kerja operator. Kemudian bagian yang kedua yaitu proses, dimana pada bagian ini data-data yang telah dikumpulkan akan diolah seperti data antropometri yang kemudian dihitung statistika datanya yang meliputi uji kecukupan, keseragaman, maupun uji kenormalan. Setelah melakukan uji-uji statistika, kemudian akan masuk ke tahap perancangan dengan metode rasional. Bagian ketiga atau bagian terakhir dari model konseptual ini yaitu output yang akan diberikan dimana outputnya yaitu usulan alat bantu yang ergonomi yang akan dimodelkan kemudian dihitung postur kerja usulannya dengan menggunakan metode REBA.

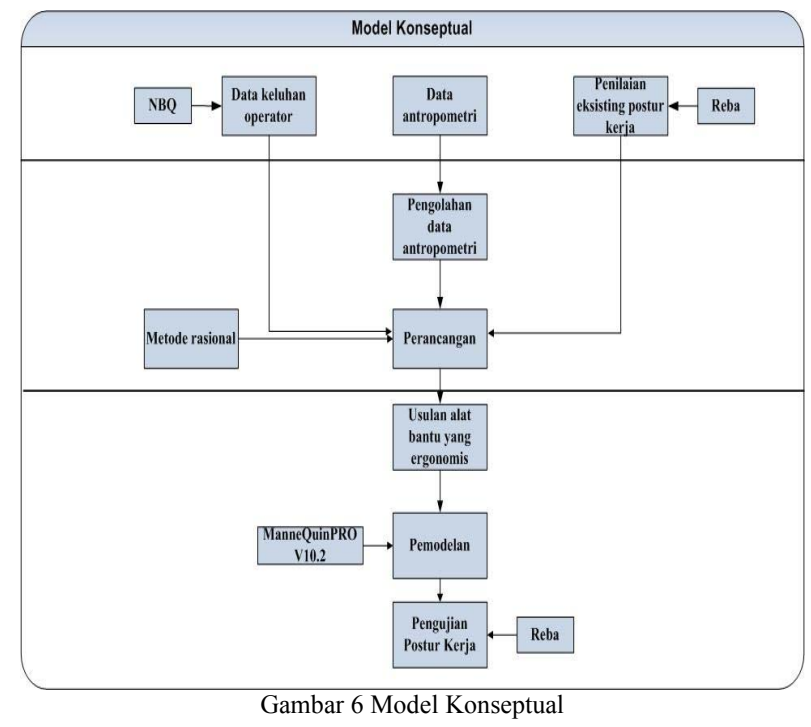

\section{ANALISIS SISTEM}

Adapun tahapan-tahapan yang dilakukan dalam analisis metode rasional yaitu:

\section{A. Clarifying Objectives}

Langkah yang pertama yang digunakan dalam metode rasional adalah clarifying objectives, langkah ini menjelaskan mengenai tujuan perancangan. Metode yang digunakan adalah objectives tree. Metode ini bertujuan untuk menjelaskan tujuan dan sub tujuan dari perancangan dan hubungan di antara keduanya.

\section{B. Establishing Function}

Metode yang digunakan adalah function analysis. Metode analisis fungsi ini menawarkan fungsi-fungsi penting dan level dari masalah yang ada. Metode ini bertujuan untuk menentukan fungsi yang dibutuhkan dan batasan sistem dari perancangan baru.

\section{Setting Requirements}

Metode yang digunakan adalah The Performance Specification Methods. Metode ini bertujuan membantu menemukan masalah perancangan.

\section{Determining Characteristics}

Dalam tahapan ini salah satu metode yang dapat digunakan adalah Quality Function Deployment (QFD). Tujuannya untuk menetapkan target yang akan dicapai oleh karakteristik teknis produk yang dapat memenuhi keinginan konsumen. Akan tetapi, kerena penelitian ini hanya membahas usulan spesifikasi 
produk maka pendekatan yang digunakan adalah pendekatan ergonomi yang mencakup bidang antropometri.

\section{E. Generating Alternatives}

Pada tahap ini mulai dicari solusi-solusi yang mungkin. Metode yang bisa dipakai adalah Morphological Chart Method. Morphological chart ini berguna untuk memperluas daerah pencarian solusi baru yang potensial dalam pengembangan alternatif (Cross, 1994). Tujuan dari pembangkitan alternatif adalah untuk membangkitkan solusisolusi rancangan alternatif atau memperluas ruang pencarian terhadap solusi-solusi baru yang potensial.

\section{F. Evaluating Alternatives}

Tahap ini adalah tahap pemilihan alternatif terbaik di antara beberapa alternatif yang ada. Metode yang digunakan adalah metode weighted objectives (pembobotan obyektif). Pemilihan dilakukan berdasarkan jumlah dari score dikalikan bobot yang menghasilkan angka terbesar.

\section{G. Improving Details}

Contoh metode yang dapat digunakan pada tahap ini adalah value engineering. Tujuan utamanya adalah untuk meningkatkan fungsi atau nilai produk dan mereduksi biaya produksi.

\section{IV.HASIL ANALISIS}

\section{A. Desain 3 Dimensi}

Agar dapat memvisualisasikan bentuk produk usulan maka, peneliti melakukan perancangan visualisasi bentuk 3 dimensi dengan menggunakan software Solidworks 2013. Adapun hasil rancangan seperti pada gambar dibawah ini:

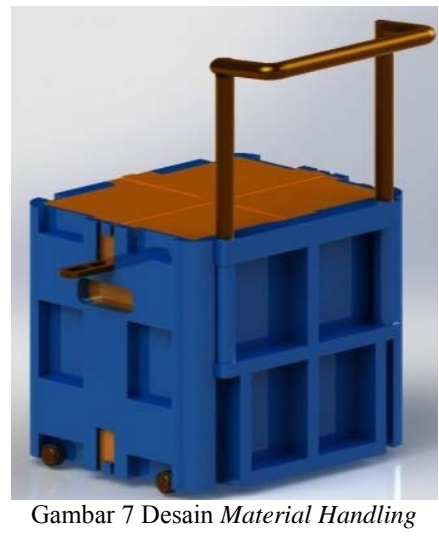

\section{B. Simulasi Gaya Tekan}

Pada gambar 9 diatas, dapat diamati bahwa walaupun dengan memperoleh tekanan sebesar $80 \mathrm{~kg}$ roda masih dapat menerima gaya tersebut sebab nilai yield strange dari material sebesar 172,339,008 lebih besar dari nilai von mises yaitu sebesar 1,441,995 N/M2.

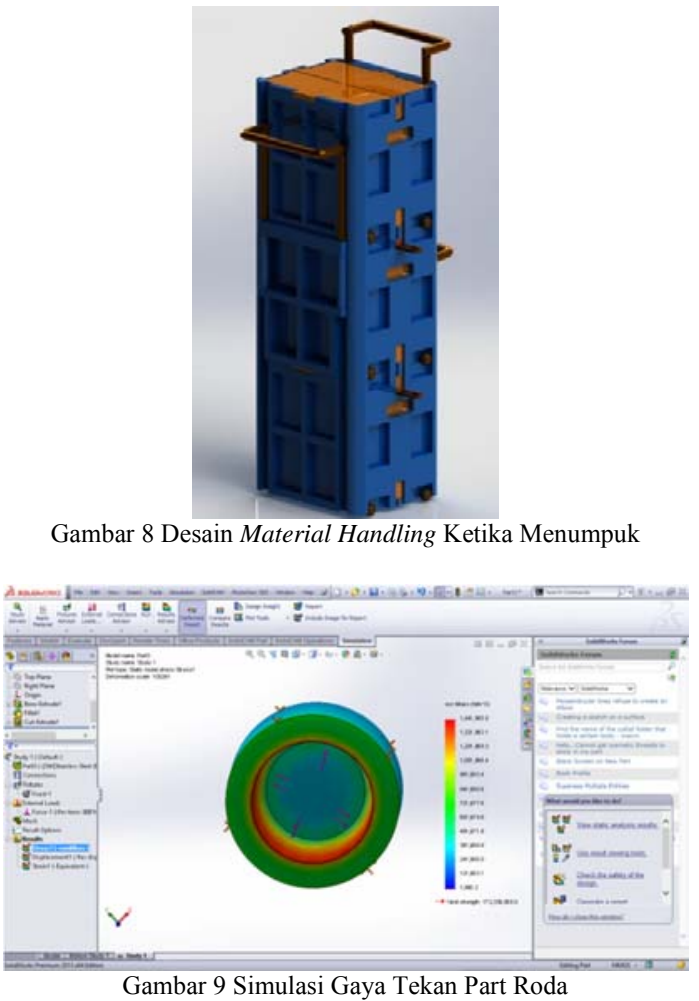

\section{Simulasi Ergonomi}

Untuk memvisualisasikan penggunaan alat bantu maka, peneliti melakukan simulasi penggunaan pada software Manne Quin PRO versi 10.2 yang ditunjukkan pada gambar-gambar di bawah ini:

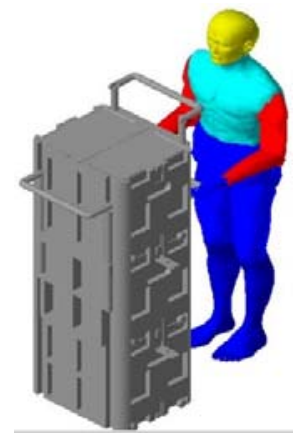

Gambar 10 Simulasi Penggunaan Material Handling

\section{Analisis REBA Material Handling Usulan}

Setelah dilakukan simulasi penggunaan produk, maka langkah selanjutnya peneliti melakukan analisis postur kerja usulan dengan menggunakan software REBA (Rapid Entire Body Assessment), dimana hasilnya ditunjukkan pada gambar 11 di bawah ini: 


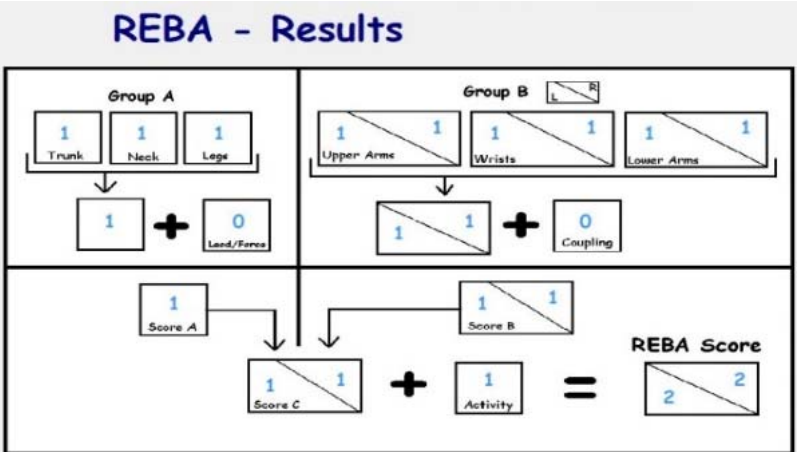

Gambar 11 Hasil REBA Postur Kerja Usulan

Nilai 2 menunjukkan bahwa level risiko MSDs pada operator kecil, sehingga penggunaan produk pada operator layak untuk digunakan.

\section{KeSIMPULAN}

Berdasarkan hasil penelitian dapat diketahui bahwa nilai REBA maksimal untuk ketiga aktivitas adalah 2, hal ini mengindikasikan terjadinya peningkatan pada nilai REBA dimana sebelunya nilai REBA eksisting maksimal sebesar 12.

TABEL 2

SKOR EKSISTING, USULAN, DAN PERSENTASE PRODUKTIVITAS

\begin{tabular}{|c|c|c|c|c|}
\hline No & Aktivitas & $\begin{array}{c}\text { Skor } \\
\text { Eksisting }\end{array}$ & $\begin{array}{c}\text { Skor } \\
\text { Usulan }\end{array}$ & Produktivitas \\
\hline 1 & Mengambil & 12 & 2 & $83 \%$ \\
\hline 2 & Membawa & 12 & 2 & $83 \%$ \\
\hline 3 & Meletakkan & 12 & 2 & $83 \%$ \\
\hline
\end{tabular}

Sehingga dapat dilihat pada tabel diatas terjadi peningkatan produktivitas sebesar 83 persen. Dengan memperbaiki postur kerja operator, maka risiko operator untuk gejala muscolesceletal disorders (MSDs) dapat dikurangi atau diminimasi.

\section{DAFTAR PUSTAKA}

[1] Cross, N. (1994). Engineering Design Methods Strategies for Product Design. Edisi 2. United Kingdom: John Wiley \& Sons, Inc.

[2] Nurmianto, E. (2004). Ergonomi Konsep Dasar dan Aplikasinya. Prima Printing, Surapa, Surabaya.

[3] Ginting, R. (2009). Perancangan produk. Graha ilmu, Jakarta

[4] Iskandar, Murdini. (2009). Perancangan Visual Display Terminal (VDT) Laboratorium Teknik Industri IT Telkom Dengan Pendekatan Ergonomi.. Jurusan Teknik Industri Institut Teknologi Telkom, Bandung.

Usulan Perancangan Material Handling yang Ergonomis Bagi Operator Loading Sayuran Buncis Dengan Menggunakan Metode Rasional (Studi Kasus di PT. ABO Farm Ciwidey)

Mohammad Fadli Setiawan; Rino Andias Anugraha; Yusuf Nugroho Doyoyekti; Ni Made Yunita Sari Dewi (hal 8 -12) 